\title{
The early years of nursing in the Dutch East Indies, 1895-1920
}

\author{
Liesbeth Hesselink
}

Before 1900 there were almost no trained nurses to be found in the Dutch East Indies. Medical progress called for qualified nurses. Initially, the solution seemed to lie in importing nurses from the Netherlands, but as they proved reluctant to travel to the colony, it was decided to attempt to train local people instead: (Indo-) European and Indonesian, ${ }^{1}$ male and female. Remarkably, while nursing was, typically, considered a woman's occupation in the mother country, the training as offered in the colony was open to either gender. Male nurses graduating from training soon outnumbered their female colleagues. The history of this attempt to introduce 'professional' nursing into the Dutch East Indies has largely been neglected by historians. ${ }^{2}$

\section{The Dutch East Indies}

The Dutch East Indies - nowadays called Indonesia - have been a Dutch colony since around 1600. It is a huge archipelago with more than 17,000 islands; the most important then and now is the island of Java. Around 1900, 60 million people lived in the archipelago, roughly half of them on Java. The population consisted of Indonesians, Foreign Orientals (mainly Chinese) and a handful of Europeans. In 1900 almost 65,000 Europeans lived on Java, together with almost 30 million Indonesians. On Java alone there was a wide diversity of population groups: Javanese, Sundanese, Madurese, Chinese, Arabs, Malay, Indo-Europeans and Europeans. Officially, Indo-Europeans did not exist: children born of a European father and a native mother were counted among the group of Europeans if the father acknowledged them as his; if not, they belonged to the group of Natives. ${ }^{3}$ 
Two services provided healthcare in the archipelago, the Military Health Service and the Civil Health Service, but were in actual fact one organisation. Throughout the nineteenth century, Western medicine in the Dutch Indies was virtually synonymous with military medicine. ${ }^{4}$ Civilians were also treated in the military hospitals. The hospitals were classified into large hospitals, garrison hospitals and infirmaries. Nursing was carried out by untrained orderlies. In addition, there were municipal clinics in the three large towns on Java (Jakarta, Semarang, Surabaya), where convicts and poor natives were treated and nursed free of charge. Here the nursing was done by untrained, often illiterate native male and female lay persons. ${ }^{5}$ Hospitals were not popular with the population in the Dutch colony, neither with the Indonesians nor with the Europeans, understandably so given the circumstances of the hospitals around 1900: 'Gloomy walls of tarred bamboo, here and there mouldy in parts, ravaged by insects, without light, with hard wooden beds, on which lay grimy yellowish brown mats, hard leather rolls for pillows, dirt floors, with red marks, here and there, from spitting sirih [betel].' Bad hygiene combined with unreliable and incompetent staff damaged the reputation of the hospitals. People of social standing - Indonesian and European - preferred to be treated at home by their relatives. Moreover, the native population laboured under the misconception that all the doctors did in the hospital was potong, literally 'cut', in this context, operate. ${ }^{7}$ As operations and other surgical techniques were considered forbidden on religious grounds and on account of adat (indigenous customs and law), not surprisingly, the hospitals were viewed with a certain amount of suspicion. ${ }^{8}$ If they were ill, Indonesians very rarely turned to Western medicine and its practitioners: simple diseases could mostly be treated by the individual himself and his or her family. For serious diseases a native healer (dukun) was called in.

However, with developments in the medical sciences hospitals evolved into institutions of scientifically based medical treatment, which, in turn, would ultimately lead to a demand for a more professional way of nursing. Many European physicians voiced their complaints at standards of nursing available; thus, the head of the Health Service, J. Haga, wrote: 'With coolies picked up from the street [to work in hospitals] and babus [female servants] stealing from the 
Government and merely staying in their job until they can get a better position, it is impossible to look after sick and injured patients properly.' Their nickname 'hospital hyenas' does not leave much doubt as to staff attitudes and practices..$^{10}$ At the 1898 exhibition on Women's Work in The Hague, H. F. P. Maasland - who had worked as a health officer in the Indies for some years - spoke up for enhancing the quality of nursing in the Dutch Indies. Only the employment of nurses who had taken exams, he declared, could bring about an improvement in 'the dismal situation .... While civilised countries have now universally come to recognize that nursing is a proper profession and that well-trained staff is a prerequisite, our colony assists its sick by means of folk who often, intellectually and morally, belong to the mire of Indies society. ${ }^{11}$ The need for professional nurses was only heightened by changes in the colonial policy.

\section{Colonial policy}

Although the Dutch had been present in the Indonesian archipelago since the early seventeenth century, fully fledged colonialism only developed in the nineteenth and early twentieth centuries. Technical and economic changes as well as a new psychological mix of both Western superiority and social concerns resulted in a renewed sense of a 'civilising mission' and a more active colonial policy. Termed the Ethical Policy, it was the Dutch version of the British 'white man's burden' or the French mission civilisatrice. ${ }^{12}$ The new Ethical Policy was officially announced by Queen Wilhelmina in the annual Royal Oration of 1901. She argued that as the Netherlands prided itself on being a Christian power, this placed its government under an obligation to imbue its policies with a moral mission towards the population of its territories. ${ }^{13}$ Rather than viewing their colony as mere patrimony and a profitable cash cow, the Ethical Policy implied a novel dedication on the part of the Dutch colonial administration to development of schools and medical services, transportation and other infrastructural improvements for the benefit of the native population. The Ethical Policy attracted more and more Europeans to the colony as engineers, educators, lawyers and doctors. In the Netherlands they had experienced good hospitals with trained 
nurses and they wanted the same quality of healthcare in the colony. The Ethical Policy increased the need for medical facilities and practitioners, as did the growth in the numbers of private companies seeking medical care for their personnel, both European and non-European. So more hospitals, more outpatient clinics, more doctors, more and better-qualified nurses were required. Now that the government took responsibility for the health of all civilians European and Indonesians alike - an independent Civil Medical Service (CMS) was founded in 1911.

\section{Private enterprise}

The government in the Dutch East Indies had so far adopted a somewhat guarded position on mission and missionary work, particularly in Islamic areas. At the time of the Ethical Policy this position changed. Missionary work and missions had been found to be beneficial in promoting healthcare and education. In the beginning the missionaries were generalists: preachers-cum-teachers-cum-doctors. Around 1900 the first fully fledged missionary physicians came to Java; they were placed in long-term missions in one location, devoting themselves entirely to treating the native population. The mission erected hospitals where they started to train native nurses: Mojowarno (East Java) and Yogyakarta (Petronella hospital) were two showpieces of the medical missions. ${ }^{14}$ At Mojowarno, pupils at the missionary school were used as male and female probationers; ${ }^{15}$ the training was given by L. L. Bervoets-van Ewijk - wife of the missionary-physician who had been a nurse before her marriage. At Yogyakarta, where no such pupils were available, domestic servants, gardeners and other unskilled workers were trained as hospital attendants. ${ }^{16}$ In Yogyakarta training was given by Jacqueline Rutgers and Johanna Kuyper, two European nurses who had come to the colony for the purpose. The Roman Catholic mission was not widely active in the archipelago until after $1925 .{ }^{17}$

Around 1900 Europeans formed societies in the cities concentrating on sick-nursing and on founding hospitals. Some were exclusively intended for Europeans; others welcomed all ethnic groups. Of a slightly different nature was the Semarang-based Society for the Promotion of Native Nursing Practices, whose aim was to promote 


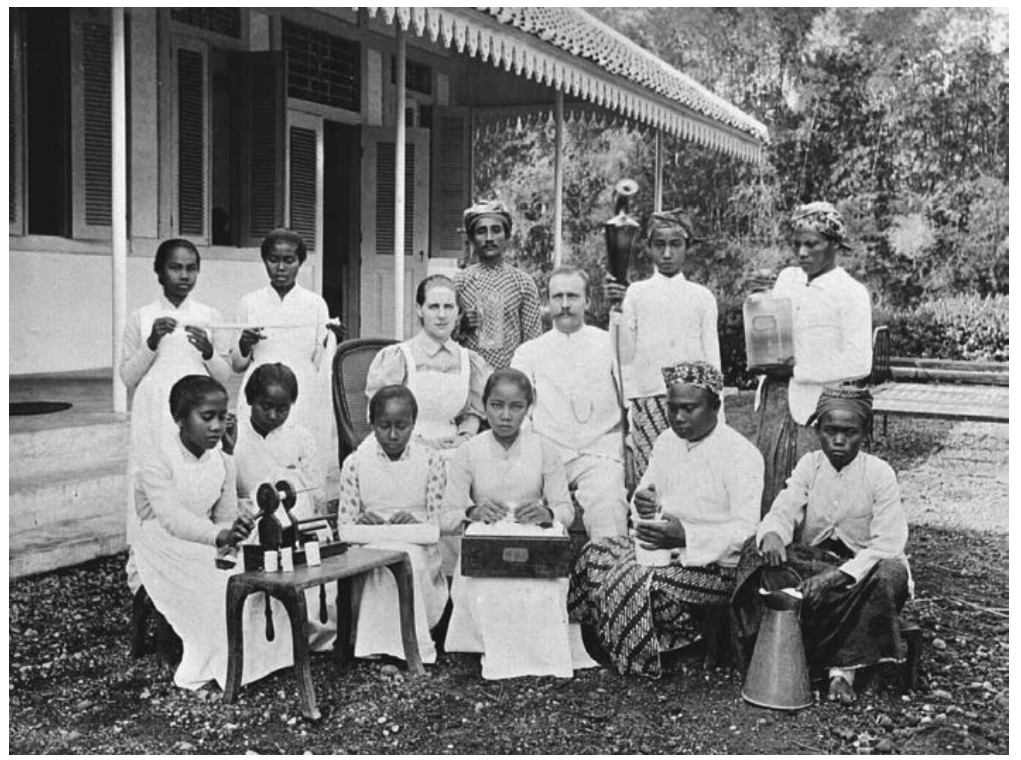

7.1 Mrs Bervoets and her husband with student nurses and student midwives in Mojowarno around 1910

the interests of native nursing - just as the mission intended to do. ${ }^{18}$ Business interest occasioned a need for medical care among companies to serve their employees, sometimes utilising existing care provisions, sometimes founding their own hospitals.

At first, qualified nurses were brought over from the Netherlands. Thus, the Jakarta-based Society for Sick-Nursing had deaconesses brought to the Dutch East Indies for its hospital - the so-called Cikini hospital - seconded by one of the deaconesses' hospitals in the Netherlands for a five-year period. ${ }^{19}$ In Jakarta they worked in the hospital or in patients' homes. ${ }^{20}$ The Society for Sick-Nursing on the East Coast of Sumatra asked the medical superintendent of a hospital in Amsterdam (Wilhelmina Gasthuis) to mediate in the posting of nurses to their hospital in Medan (Sumatra). ${ }^{21}$ Where Britain had just one Colonial Nursing Association, which provided nurses for the colonies, ${ }^{22}$ in the Netherlands there were a number of institutions through which nurses could be recruited for the Dutch East Indies. 


\section{The pioneers' experiences}

The working conditions in the colony were obviously very different from those in the motherland, except for the long working days, although the extent of the differences depended on where the nurses were posted. They could be seconded to a hospital in a city like Jakarta with a great many European patients, or at the other extreme, to a mission hospital in the bush in North Sulawesi that had native patients only; or they spent their time nursing European patients in their homes. Those working in the bush had to work much more independently than they would in the Netherlands: owing to the poor infrastructure a doctor was often hours away. Moreover, there were fewer doctors, anyway.

The nurses also had the climate to contend with. By no means everybody could cope with the heat and some were so ill that they had to return to the Netherlands. Before they left for the Indies, they had to pass a medical examination; apparently, the importance of a strong constitution was recognised.

There was no preparation whatsoever for the work in the tropics. The first impressions of Barbara Lind, a nurse who of her own accord resigned from the Amsterdam Wilhelmina Gasthuis to be posted to Aceh by the Dutch Red Cross, raises questions about how she - and other nurses as well - might have pictured her place of work prior to her arrival. She thought the military hospital in the capital of Aceh awfully cheerless: 'How I missed the pleasant wards of the W.G. [the Wilhelmina Gasthuis] in the beginning, the tables and the smaller ones with their beautiful plants, the night lamp with its beautiful lampshade, the bedspreads, the little bedside tables, yes, even the chairs! ${ }^{23}$ Apparently, she did not - or could not - form a mental picture of what awaited her, least of all the situation in a military hospital in Aceh, where, after all, a war was still being waged. ${ }^{24} \mathrm{~A}$ similar kind of surprise emerges from a letter by Miss C. M. E. Kuyper. She described her first impressions of the Petronella hospital in Yogyakarta, where her sister worked as a missionary nurse and where she stayed for a few days in May 1911:

At first sight, the wards created a strange impression. To the Dutch eye, something bare and gloomy would seem to hover over the whole place, the beds want sheets, and only have a blanket, which during the day lies folded 
up at the foot of the bed, on the beds there is no mattress, just a plaited mat ... The pillows have white pillow-cases but the patients themselves wear mostly dark sarongs, preferably with a dark kebaya [the traditional blouse-dress combination]. Here, a Dutch woman misses all the pure white sheets, the white nightclothes and the cheerful sunlight pouring in. ${ }^{25}$

Nurses were advised to at least learn Malay before travelling out to the colony in order to be able to communicate with native patients and with the native (student) nurses. The indigenous patients were mostly poor or impecunious Indonesians, who seldom spoke Dutch and often did not speak Malay either. ${ }^{26}$ It was therefore desirable for nurses to be able to speak a local language, such as Javanese, as well. Often, upon their arrival in the archipelago, nurses were put to work straightaway, so there was very little time, if any, in which to acquire a fair grasp of Malay or Javanese. Obviously, this created enormous barriers in their contacts with students and patients.

Nurses freshly arrived from Europe had to become accustomed to the habits of the patients and their families. More well-to-do patients often took along their own babus, who did the washing and mopped the room. One missionary nurse remarked: 'I have meanwhile become used to the fact that when I do my last rounds in the hospital for the evening, many patients do not lie in their beds but under them. We have to give up quite a lot of our Western ideas. ${ }^{27}$ Another nurse wrote: 'The visitors would either sit on the patient's bed or lie in it while the patient was walking outside for a while; others sat on the ground; well, they have to since there are no chairs. ${ }^{28}$

\section{Training young Indonesian men and women}

However, the number of nurses from the Netherlands was wholly insufficient to meet the colony's increased demand for competent nursing staff. ${ }^{29}$ As a result, around 1900, private initiatives began to emerge, designed to train (Indo-)European young women in the Indies. ${ }^{30}$ The Society for Sick-Nursing in the Dutch East Indies had opened a training course in Jakarta in 1897, but lack of applicants meant that the first course did not begin until 1900. ${ }^{31}$ Then six students started on the three-year course: five resident students with one student living out. Primary school education was a prerequisite for entry into the training, along with a certificate of good moral conduct 
issued by a religious instructor. ${ }^{32}$ The European physicians on the spot offered their services as teachers on the course, free of charge. The theoretical element of the training course generally proceeded well enough, but the practical part caused problems. Of the six students, three dropped out prematurely. A call in the local newspapers to fill the places that had fallen vacant did not have the intended effect. ${ }^{33}$ The board could not but conclude that it was very hard to train young Indies women to be nurses. They explained the matter thus: '[T]he position of nurse holds but little attraction for the girls and women in the beauteous Insulindia, as a duty, it is too little valued, the work is still considered as insignificant, ignorance of its character and nature form the cause hereof. ${ }^{34}$

When the plan to train (Indo-)European women in the archipelago failed to alleviate the nursing shortages, the focus shifted to training young Indonesian men and women. European physicians took their training in hand on their own initiative. Doctors in the city of Semarang proved most successful in this endeavour, and provided the model for training courses elsewhere in the archipelago. Some students came from far afield, even from other islands, to train in Semarang. ${ }^{35}$ N. F. Lim, second municipal physician in Semarang, began to train native boys, ${ }^{36}$ while his fellow townswoman, private physician Nel Stokvis-Cohen Stuart, trained the girls. ${ }^{37}$ Her initial efforts to teach native girls to be nurses were disappointing and difficult. After many failures, she abandoned her plan, but not for long. After she saved the life of a seriously sick Javanese baby by taking him into her house, she acquired a certain fame among the native population. Thus encouraged, the head of a village near Semarang contacted Stokvis introducing his fourteen-year-old daughter, Soetarmijah (known as Mien); the girl very much wished to train as a nurse. Mindful of the fiascos of the past three years, Stokvis was reluctant to embark on the exercise, but the father managed to persuade her that his daughter was in no hurry to get married but was anxious to continue her studies. At first Mien was given theory lessons by Stokvis at her home. Hands-on experience and practical training would be in the clinic. Lim, by now the director of the hospital, did not object to Mien working on the women's ward but initially did not want to admit her to the lessons for his male students as he did not have enough confidence in 
the ability of young Javanese women to study. Eventually, he capitulated and allowed her to participate in the male students' lessons. ${ }^{38}$ In the end, Mien passed her exam and went on to work as a nurse.

The problems encountered by Stokvis were closely connected with the position young women occupied in Indonesian society. Before they could train as nurses, girls were required to have finished primary school. In principle, girls from poor families did not attend school. Girls from the middle and upper classes often did but it was considered culturally improper for upper-class girls - the ones among the population who could afford to study - to live outside their parents' home when they were of marriageable age (fourteen to sixteen). The poor reputation of the hospitals made them appropriate workplaces only for lower-class women and for women whose reputations were already dubious. ${ }^{39}$

\section{Government regulations}

It was not only in the mission and Semarang hospitals that physicians began to train medical personnel of their own accord. Elsewhere in the archipelago, doctors undertook similar initiatives. J. H. F. Kohlbrugge, for instance, awarded the young men he had trained the made-up title of hulpgeneesheeren (ancillary doctors). ${ }^{40}$ In order to call a halt to this uncontrolled practice, the government decided to regulate matters in $1911 .{ }^{41}$ Students received an allowance for housing, clothing and food; a maximum of 100 students across the entire archipelago were eligible for this allowance. To be admitted to the training the following requirements had to be met: the students should be at least sixteen years of age, in good health and have a primary school education. The number of students subsidised by the government grew exponentially; in 1917 the maximum for Java was set at 200. Despite this increase, the demand remained higher. ${ }^{42} \mathrm{~A}$ year on, the maximum was again raised, this time to $500 .{ }^{43}$ In Semarang - and maybe elsewhere, too - students were trained without being subsidised by the government but at the Society's expense. ${ }^{44}$

Once the students were admitted, the three-year training course started with a combination of theory and practical lessons. Their education in nursing practice was provided by a European female nurse, 
who covered sick-nursing, infant care and such practical matters as handling and bathing seriously ill patients. All the training was conducted in Malay, ${ }^{45}$ which sometimes gave rise to problems when, for instance, girls were tackled about their conduct towards patients. As Stokvis recalled: '[I]t is difficult to discuss such sensitive matters with the students since Malay is neither for them nor for us our mother tongue. ${ }^{36}$ What greatly contributed to the eventual success was the fact that during their training, the girls - just like the boys - were housed in a kind of boarding school, albeit a rather grand term for the housing in question.

In 1915 the colonial government imposed an exam in sick-nursing. ${ }^{47}$ To be awarded a diploma, the candidate had to be at least twenty years of age and able to produce a certificate of good moral conduct. ${ }^{48}$ Once graduated they became mantri nurses, an official function in the CMS. ${ }^{49}$ Mantri refers to a lower civil servant, a foreman, a supervisor; the word is used to form all manner of compound nouns. Here, mantri nurse is used to indicate the difference from those who carried out unqualified nursing work.

Having acquired the diploma of mantri nurse, the graduates could - if found suitable - undertake a follow-up course to obtain the so-called mantri nurse diploma first class. After practising for two years, during which time they were also taught to do laboratory and pharmacy work, they could take the exam. Then, they were authorised to practise more or less independently, treating the most common diseases, to administer first aid in cases of disease or accident and to be in charge of a ward or an outpatient clinic..$^{50}$ This latter function was exclusively performed by male nurses. In the outpatient clinic they could recognise the more common diseases and treat them, while the more complicated cases had to be passed on to the nearest hospital. These nurses' task, then, was a curative one.

After they had obtained their nursing diploma, young women could also choose to do a follow-up course for midwives. Stokvis had noticed that most parents found a midwifery training to be a more attractive proposition for their daughters than the nursing course, the profession of nursing being unknown to native society. ${ }^{51}$ On the other hand, the function of a midwife was well known among the native population; it constituted one of the specialisms of the dukun, who in that capacity would be called dukun bayi. The 
midwifery training constituted of a two-year scheme in which the student midwives took turns working in one of the hospitals and did shifts as district nurses as well. The graduates worked for the government. They were generally allotted a post close to their family; if they were not, this often constituted a reason for them to leave. ${ }^{52}$ These newly trained midwives experienced a great deal of competition from the dukun bayi, the traditional birth attendant, as they carried out their work in practice, in the village. With their youth they were no match for the trusted figure of the much older and more experienced dukun bayi.

\section{The image of nursing}

In the Netherlands, nursing summoned up images of a typically female occupation where qualities such as charity and self-sacrifice were central; and, in actual practice, it was primarily women who entered into the profession. ${ }^{53}$ These women preferably came from the cultured classes, since only such women were able to exert a civilising influence on the other staff members and on the patients. ${ }^{54}$ This image also prevailed among the Europeans in the colony, including the founders of the Cikini hospital in Jakarta, who saw nurses as women 'who with a trained and soft hand know how to ease the distress of the sick person in so many ways, support him with delicate tact, at difficult moments with a calming or uplifting word and take care that the doctor's orders are followed strictly. ${ }^{55}$ Their role as carers for the native population was further accentuated in their annual report, which stated:

We emphasise the noble mainsprings that guide our deaconesses in their work, since it is our well-established conviction that sick nursing in the Indies takes to heart the fate of all classes of society and that it can only serve humankind, without regard to rank or class, if the practice of Christian virtues is its principal driving force. ${ }^{56}$

Apparently, these noble mainsprings were reserved for women: 'Indeed, there is well-nigh no finer vocation imaginable for woman, our superior in love and devotion, than to devote her strengths to subservient love, which expresses itself in nursing the sick. ${ }^{57}$ The later governor-general A. W. F. Idenburg exulted in a 
report of his visit to the Petronella missionary hospital, where he had made the acquaintance of the two European nurses: 'What wonderful gifts woman has received with which to nurse the sick. ${ }^{58}$ Others, like a certain De H., expressed a similar ideal image of a nurse:

Woman is a born sick nurse .... A nurse or female attendant who performs her tasks in accordance with the principles that nowadays apply to the profession, and possesses both heart and mind with it, must, in our estimation, be placed very highly. She deserves to be honoured as a priestess of mercy. ${ }^{59}$

The image of the profession fitted in very well with the civilising mission that the Dutch and other colonisers had set themselves around 1900. In a letter to the editor of a journal in the Netherlands, a woman who herself had been a long-term patient in the Cikini hospital wondered why so few nurses felt a calling to come to the Indies: 'How come that our neighbours can feel a sense of vocation to go to the colonies while the Dutch deaconesses cannot? Or do they indeed sense such a vocation but suppress it and if so, for reasons that incline to selfishness. ${ }^{\prime 60}$ Stokvis was of the opinion that one should not so much go to the Indies because of the personal advantages as

for the work itself .... Because in the Indies we are strapped for staff; I mean staff who are engaged in social work, and who are not solely, nor mainly, after finding a means to support themselves, but who realise in how many respects the country and its population are still behind and how much they still lack, and who consider it a duty and a privilege to help them catch up. ${ }^{61}$

All in all, these views exuded a high moral tone.

\section{Image-building during the training}

The main task of most European nurses was to train Indonesian nurses. While, obviously, nurses in the Netherlands were used to training students, Dutch students were not to be compared with those in the colonies, where elementary school education was wholly or partially lacking and where the trainers differed widely from their students as to cultural background. The sources also make clear that providing training in the Indies was not exactly a sinecure. Complaints about the students' poor sense of responsibility, their different standards and values are legion: 
That a made-up list of temperatures is not the same as one based on careful observation is not immediately obvious to him. Being hard on a patient, if need be, is something he finds difficult, cleaning a wound thoroughly when this is painful, when the patient puts up a resistance, may at times be an exercise in patience that weighs too heavily on him. ${ }^{62}$

L. L. Bervoets-van Ewijk, the wife of the missionary-physician in Mojowarno mentioned earlier, met with similar experiences when training young native women to become nurses:

What is lacking, however, is a serving out of love; they help the sick out of obedience born out of a love for us; but comforting and cheering up the sick of their own accord, that is something we have not seen yet .... [T] he true interest in her patients is usually still missing. ${ }^{63}$

Physician Miss W. Valk, who was in charge of the Budi Kemuliaän maternity clinic in Jakarta around 1920, recounted how the student nurses loved the lessons, the theory, but did not relish the work. She related 'stories of lovelessness, cruelty even, towards sick children, of duty being shirked and of a lack of responsibility, of such magnitude, that one cannot but conclude that the idea of a general charity is not part of her mentality.6 ${ }^{64}$ This quotation comes from the book that in later years formed part of the required reading for nurses as they prepared for their work in the tropics and that thus immediately conveyed to them a certain image of the natives.

These supposed characteristics of Indonesian students sat uncomfortably with the image that the Europeans had of the profession. It was therefore essential that the course taught standards and values that were in line with the Western image. The European nurses held the key to this. Not only did they have to teach the various practicalities of nursing but they also had to live up to the image of the profession. A minister wrote to a European missionary nurse: 'The duty of a nurse in the Indies is especially an educational one. She has to mould young ladies into nurses who can work among their own people. The idea is not so much for them to become sisters but rather the educator. ${ }^{3}$ It was not just the mission that imposed heavy demands on European nurses. Much the same happened in the Semarang hospital, where Stokvis saw the European nurses especially as role models: 'In all this, European female nurses are necessary, the best, but it is not easy to get good European nurses in the Indies. ${ }^{36}$ 
Fortunately, there were also qualities that made young native women perfectly suited for nursing. A Dutch woman visiting the Petronella hospital remarked on how the Javanese nurses went

round the wards on their bare little feet without a sound .... The Javanese are exquisite in their movements, very composed, they are fine and slender in shape, they always walk upright; their tone of voice is softly muffled, they are usually deft, and of a practical bent. All qualities that make the young Javanese girl so eminently suited for nursing. ${ }^{67}$

It was important that the training led to a profession with status. Graduates had to earn a certain standing within the native community, if only to introduce the new profession to Indonesian society and to reduce resistance to Western medicine. Stokvis thus expressly wanted to train students from among the higher classes of society. Thanks to her good relations with the native elite, she succeeded in training young women from the nobility to become nurses. And indeed, the Semarang training course swarmed with titled students, both male and female. ${ }^{68}$ Especially among the young women, their background could pose practical problems. Stokvis sighed: 'It is quite a job to drum into the students that they have to follow the instructions from the doctors, even when the person concerned is a Raden Ayu [title of a married lady of noble birth] or someone else from the aristocracy. ${ }^{69}$ Similarly, descent played a role in the students' relations with the patients:

A 'higher-class' patient will be given more attention, more delicacy is brought to the care given. And where appropriate, a wish or a refusal from such a 'higher' patient weighs decidedly more heavily than the doctor's instruction .... Conversely, the students' conduct towards the ordinary patients frequently leaves much to be desired. ${ }^{70}$

At the mission, it was sometimes ordinary young women who received training, sometimes young ladies from the upper classes. In a mission hospital in the Minahassa, which was run by two qualified Dutch nurses, some young ladies from the upper classes, former students of the Boarding School for the Daughters of the Heads and Notables in Tomohon, trained to become nurses. ${ }^{71}$ One of the young ladies, the daughter of a district head, was taunted frequently by her girl friend to the effect that the work was far beneath her. " "Oh," she said, "if Miss De Ruyter and Miss Schoch 
do not deem it beneath them, then I do not need to be ashamed of it, either, I should think" ';2 a clear demonstration that in practice Dutch nurses really did serve as role models for their native students. But it also illustrates the negative image that the nursing profession had among the native elite. We encounter something similar in Semarang, where 'a small school fight between our young ladies and the female students of a Semarang Native school [broke out], where one of our young ladies was told with a sneer: "oh yes, in the street you look very nice, but in the hospital you have to empty buckets and pots!" ${ }^{73}$ Bervoets also concluded that the profession had no standing within Indonesian society, neither with Muslims nor with Christians. ${ }^{74}$

Because these Dutch nurses served as role models, it was important that the nurses came from good backgrounds themselves. The Indies newspapers thus stressed the descent of the first two European missionary nurses, Jacqueline Rutgers and Johanna Kuyper: 'It cannot but inspire respect, that ladies of good birth come to the Indies to undertake such a labour of love and charity.' And elsewhere: 'These most talented ... distinguished ladies nurse the most hideous cases as if it were nothing. One is not only full of admiration for these sacrificial acts of love, but also full of wonder that highly civilised ladies undertake such labour. ${ }^{35}$ They were the daughter of an Amsterdam professor, and of the then prime minister, respectively.

In Europe descent also played a role in the evolution of the nursing profession. In the Netherlands, Lady Jeltje de Bosch Kemper (1836-1916) devoted herself to turning sick-nursing into a profession of civilised women. Just like Florence Nightingale (1820-1910), the icon of British nursing, she came from a distinguished family.

\section{Gender, race and class}

With a topic like training native men and women in a colonial context, it is useful, lastly, to devote some attention to such aspects as gender, race and class. Gender, race and class were factors in classifying the sick in the hospitals. There were wards for several classes, with men and women also being segregated. In addition, there were often different wards for each race. Class and race did not coincide, 
though: both Indonesians and Europeans could be classed as indigent or impecunious. Gender, class and race also played a role in the nursing itself. If possible, the richer Europeans would be taken care of by European nurses, necessarily all females, as there were no male European nurses or midwives in the colony. The board of directors of the Cikini hospital reasoned that it would harm their competitive position among other similar institutions if they no longer worked with European nursing staff. ${ }^{76}$ A European female nurse was thus the sole prerogative of the rich and distinguished. However, given the small number of European nurses, most Europeans and Indonesians were nursed in hospitals by Indonesian nurses, with male patients cared for by a male nurse and female patients by a female nurse.

Class consciousness was also evident among the native population. The missionary hospital in Mojowarno, for example, had a separate ward for prijaji, the native elite - as did most other hospitals. ${ }^{77}$ Missionary nurse Jacqueline Rutgers spotted a strategic advantage to the presence of prijaji as patients: 'We are getting more and more prijaji (Jav. nobility) in the hospital; this causes more nursing work; they always need to have a separate room. But it is so good for the influence of Christianity. ${ }^{78}$

Given the image of the nursing profession outlined above, it is striking that in the Indies not just native women but native men as well were trained from the very start to become nurses. Looking at the numbers, it would seem that very soon there were more male than female native nurses; in 1921, 171 male nurses were employed by the CMS, compared with 45 female nurses. ${ }^{79}$ Training men to become nurses raises questions both about the government and about the native men themselves. There were several reasons why nursing attracted Indonesian men. There were few possibilities for vocational training in the Indies, and in colonial times the title mantri had a certain status as it was the title of foremen or supervisors. Moreover, there were many possibilities to continue one's education after graduating from the nursing course, for instance, to do laboratory work, assist in an operating theatre, become a hygiene and public health promoter or become the head of a permanent outpatient clinic. In the outpatient clinic they treated patients rather as a doctor than as a nurse. In practice, they were also called dokter desa (village doctor). 
In other words, nursing opened the way to many jobs with status, especially for men. The greater mobility of males in the local cultural context, necessary for some of these jobs, could have been a reason for the government to favour men in these positions. The government may have thought that Indonesian men would fit the female image of nursing because native men, especially the Javanese, were seen as submissive and servile. ${ }^{80}$ Being subservient to the physician would pose no cultural problem for them. Some Europeans even openly doubted whether Indonesians were at all capable of working independently without being supervised by a European. ${ }^{81}$ However, Javanese social structure was characterised by fluid gender systems and subtle gender boundaries; ${ }^{82}$ in their eyes, then, there may not even have been typically male or female professions.

Two types of nursing could be said to have come into being in the Indies: on the one hand, there was the female model of nursing (care-giving in the hospitals). This was carried out by both male and female nurses, each nursing patients of their own sex. They were closely supervised and had to carry out the doctor's instructions. On the other, a male model existed which focused on technical skills such as laboratory and operating-theatre work, independent roles like that



7.2 Midwife and student midwives at Semarang around 1910 
of health-promotion officers or heads of outpatient clinics. The latter had a curative task and acted as substitute for the physician. Many European physicians considered it risky for a curative task to be carried out by someone with insufficient training, ${ }^{83}$ and formally, the medically qualified doctor from the nearest hospital was supposed to visit the outpatient clinic weekly but in practice this did not happen very often.

The proportionately smaller number of female native nurses was the result of the position of Indonesian women in society, as described earlier. The number of native girls who attended school, a prerequisite for admission to the nursing course, may have risen over the years but nevertheless remained small. ${ }^{84}$ In Semarang the influx of young women was large (eighty-six in 1915) but the majority (sixty-one) dropped out as they did not meet the admission requirements. ${ }^{85}$ Upon graduation most young women would have married, as was the custom in indigenous society. In the Netherlands, marriage was (until well into the twentieth century) a reason for dismissal and it is likely that much the same applied in the Indies. In any case, native nurses from the Petronella hospital and the Semarang hospital stopped working after they got married. ${ }^{86}$ By contrast, the profession of mantri midwife was open to married women. This might explain the specialism's popularity, besides the natives' familiarity with the occupation of midwife. Married male nurses were allowed to continue in their roles. ${ }^{87}$

\section{Conclusion}

By 1920 professional nursing had obtained a firm footing in the Dutch East Indies since the arrival, in 1895, of the first qualified nurses from the Netherlands. The government had laid down clear admission and examination requirements. The training courses had become the responsibility of the heads of the large hospitals, with the hospital in Semarang having the most students. The young native men and women had quickly found their way to nurse training, one of the few training opportunities funded by the government in the archipelago. The government set a maximum number of students that could be funded to follow the course, thus restricting their influx. In 1921, over 100 young men were rejected in Semarang 
alone, indicating its growing popularity as an occupation. ${ }^{88}$ Those who had been trained with government funding subsequently joined the civil service.

The situation in the hospitals had clearly improved when compared to their condition at the turn of the century: new hospitals had been built and the quality of the nursing staff had improved enormously. Thus, the number of native patients in hospitals increased tremendously in an absolute sense, although remained a relatively small percentage of the indigenous population as a whole. However, the native population and especially women continued to have an aversion to Western medicine. This was not so much due to the costs, since nursing care in government hospitals and government-funded hospitals was free for the indigent or impecunious. Travelling expenses fell to the patient, though, and this may have had a restricting influence on the use of hospitals. Resistance to Western medicine, however, was the greatest obstacle; but with time, this dwindled as more Indonesians received a Western education.

\section{Notes}

1 The term Indonesia did not come into use until the 1920s, but it has been used here for the sake of clarity as have current names of cities (thus, Jakarta rather than Batavia) and modern spelling (thus, babu rather than baboe).

2 Only the anthropologist Rosalia Sciortino has addressed the topic. See her thesis: 'Care-takers of cure: a study of health centre nurses in rural Central Java' (Vrije Universiteit Amsterdam, 1992), pp. 48-80.

3 L. Hesselink, Healers on the Colonial Market: Native Doctors and Midwives in the Dutch East Indies (Leiden: KITLV Press, 2011), p. 9.

4 A. H. M. Kerkhoff, 'The organization of the Military and Civil Medical Service in the nineteenth century', in A. M. Luyendijk-Elshout et al. (eds), Dutch Medicine in the Malay Archipelago 1816-1942 (Amsterdam and Atlanta, GA: Rodopi, 1989), p. 12.

5 Hesselink, Healers on the Colonial Market, pp. 36-7.

6 O. Degeller, 'Inlandsche ziekenverpleging', part 1, Bulletin van den Bond van geneesheeren in Ned.-Indië, 19 (1910), p. 1.

7 N. Stokvis-Cohen Stuart, 'Plan tot instelling eener wijkverpleging', Bulletin van den Bond van Geneesheeren in Ned.-Indië, 151 (1916), p. 8.

8 L. Th. Mayer, De Javaan als doekoen, een ethnografische bijdrage (Weltevreden: Kolff, 1918), p. 5. 
9 J. Bijker et al., Rapport der Commissie tot Voorbereiding eener Reorganisatie van den Burgerlijken Geneeskundigen Dienst (Batavia: Landsdrukkerij, 1908), p. 96.

10 Kerkhoff, 'The organization of the Military and Civil Medical Service', p. 17.

11 H. F. P. Maasland, 'Ziekenverpleging door vrouwen', paper presented at the 'Conference to discuss the work done by women in various societal areas of our Indies possessions', 1898, pp. 1, 5.

12 E. Locher-Scholten, Women and the Colonial State: Essays on Gender and Modernity in the Netherlands Indies 1900-1942 (Amsterdam: Amsterdam University Press, 2000), p. 16.

13 H.W. van den Doel, Het Rijk van Insulinde: opkomst en ondergang van een Nederlandse kolonie (Amsterdam: Prometheus, 1996), p. 157.

14 Now known as Bethesda Hospital.

15 Sciortino, 'Care-takers of cure', p. 53.

16 Sciortino, 'Care-takers of cure', p. 53.

17 José Eijt has written on Catholic nurses who came to the colony after 1925, We waren er altijd: zusters in zorg en verpleging, Franciscanessen van de H. Elisabeth 1880-2008 (Breda: Van Ierland, 2009). J. Eijt and S. Hautvast, Een missie in de marge: Dochters van Onze Lieve Vrouwe van het Heilig Hart in Nederland en Indonesië 1911-2000 (Hilversum: Verloren, 2002).

18 The Vereeniging tot bevordering van de Inlandsche Ziekenverpleging was approved by order of the colonial government (Gouvernementsbesluit no. 42, 21 January 1915). However, the society was already in existence, as the statutes had been submitted to the Governor-General for approval in August 1914, Tweede jaarverslag van de Vereeniging tot Bevordering van de Inlandsche Ziekenverpleging (Semarang: H. A. Benjamins, 1916), p. 18 (hereafter Jaarverslag Semarang).

19 Deaconesses are Protestant nurses carrying out nursing activities out of charity; 'Sixth Annual Report Vereeniging voor Ziekenverpleging in Nederlandsch-Indië, in Het Nieuws van den dag voor Nederlandsch Indië (29 July 1902).

20 'Fourth Annual Report', in Bataviaasch Nieuwsblad (21 August 1900).

21 'Second Annual Report Vereeniging voor Ziekenverpleging ter Oostkust van Sumatra', in De Sumatra Post (4 September 1901).

22 In 1918 the name was changed to Overseas Nursing Association.

23 B. Lind, 'In het militair hospitaal te Kotta Radja', Maandblad voor Ziekenverpleging, 12 (1901-02), 81-2.

24 From 1873 until 1914 the Dutch fought a long and bloody war against the Achenes. The population remained rebellious until well after the war had ended.

25 16th jaarverslag der Vereeniging 'Dr. Scheurer's Hospitaal' (Petronella Hospitaal) (1912), 13-18 (hereafter Jaarverslag Petronella). 
26 E. Siebenga, 'Het werk van de Hollandsche verpleegster bij den dienst der volksgezondheid in Indië, Maandblad voor Ziekenverpleging, 41 (1931), pp. $114-16$.

27 Memorandum 'Het ziekenhuis te Tobelo', n.d. [probably the annual report by Sister Jansje Lambregtse, from the missionary hospital in Tobelo; written towards the end of May 1923], Utrechts archief, Raad voor de Zending (toegangsnr 1102-1), inventory no. 2331.

28 Lind, 'In het militair hospitaal', 81-2.

29 In 1913, thirty-eight qualified nurses were employed in institutions in the Dutch Indies; in addition, an unknown number were employed by the mission and/or worked as private nurses in domiciliary care, C. E. Benjamins, Het Juliana-ziekenhuis te Semarang (Amsterdam: Van Rossen, 1913), p. 24.

30 The target group was made up of young women born in the colony, either to European parents or of mixed descent.

31 Vierde jaarverslag van de Vereeniging voor Ziekenverpleging in Nederlandsch-Indië (Batavia: Albrecht, 1900), p. 10 (hereafter Jaarverslag Batavia).

32 Het Nieuws van den dag voor Nederlandsch Indië (18 January 1901).

33 Het Nieuws voor den dag voor Nederlandsch Indië (29 July 1902).

34 J. A. J. Meijer, Gedenkboek 40 jaar ziekenverpleging Koningin Emma ziekenhuis ('Tjikini') Vereeniging voor Ziekenverpleging in Ned.-Indië 1895-1935 (Batavia: Kolff, 1935), p. 10.

35 The young women came from Ambon, the young men from Sumatra, Jaarverslag Semarang, 5 (1919), 4, 6 and (1920), 4.

$36 \mathrm{~N}$. Stokvis-Cohen Stuart, 'Over Inlandsche ziekenverpleging in Nederlandsch-Indië, De Indische Gids, 37:1 (1915), 795 (paper presented at a meeting at the Red Cross, The Hague, 14 April 1915).

37 For more information, see L. Hesselink, 'Nel Stokvis-Cohen Stuart (1881-1964), her role in educating female nurses and midwives in the Dutch East Indies', in Hans Pols, John Harley Warner and C. Michele Thompson (eds), Translating the Body: Medical Education in Southeast Asia (Singapore: Singapore University Press, forthcoming).

38 Stokvis-Cohen Stuart, 'Over Inlandsche ziekenverpleging, 797-800.

39 N. Stokvis-Cohen Stuart, 'De huidige koers ten aanzien van de gezondheidszorg in Indië, Indisch Genootschap, Verslagen der vergaderingen over de jaren 1926-1930 (1930), pp. 19-22.

40 J. H. F. Kohlbrugge, 'Geneeskundige hulp voor Javanen', Vragen des tijds (1904), 15 [offprint].

41 Gouvernementsbesluit 6 August 1911 no. 31 (including the alterations by Gouvernementsbesluit 9 August 1914 no. 33 and 29 May 1915 no. 42) included as Appendix 1 in Jaarverslag Semarang, 2 (1916), pp. 15-18.

42 Jaarverslag Semarang, 4 (1918), p. 5.

43 Gouvernementsbesluit 27 July 1918 no. 43, Jaarverslag Semarang, 5 (1919), p. 3. 
44 Eighteen out of a total of fifty-five students, Jaarverslag Semarang, 2 (1916), pp. 11-12.

45 Jaarverslag Semarang, 2 (1916), pp. 7-9.

46 N. Stokvis-Cohen Stuart, De inlandsche ziekenverpleging te Semarang (Semarang: H. A. Benjamins, 1916), pp. 12-14.

47 Staatsblad van Nederlandsch-Indië 1915 no. 514. Earlier - Gouvernementsbesluit 6 August 1909 no. 31 - an exam had been mentioned as well; for this, see Staatsblad van Nederlandsch-Indië, 87 (1909).

48 Bijblad op het Staatsblad van Nederlandsch-Indië, no. 8378.

49 Staatsblad van Nederlandsch-Indië 1912 no. 87.

50 Staatsblad van Nederlandsch-Indië 1919 no. 438.

51 Stokvis-Cohen Stuart, 'Over Inlandsche ziekenverpleging', 801.

52 Jaarverslag Semarang, 9 (1923), p. 8.

53 In 1900, the Netherlands had 865 qualified female nurses, with a mere 48 qualified male nurses. The number of male nurses who were members of the Dutch Union of Sick-Nurses (de Nederlandsche Bond voor Ziekenverplegers) in the period 1901-21was at most 50 against a maximum of well over 4,000 female nurses. C. Bakker-van der Kooij, 'Mara. Pleegzuster zijn. Ontwikkelingen in de ziekenverpleging en de organisatiepogingen van verpleegsters in Nederland, 1870-1920', in Josine Bok et al. (eds), Tweede jaarboek voor Vrouwengeschiedenis (Nijmegen: SUN, 1981), pp. 193-222, esp. 193, 203.

54 Bakker-van der Kooij, 'Mara. Pleegzuster zijn', p. 211.

55 Jaarverslag Batavia, 1 (1897), p. 3.

56 Jaarverslag Batavia, 1 (1897), p. 4.

57 Jaarverslag Batavia, 2 (1898), p. 10.

58 Jaarverslag Petronella, 5 (1901), p. 52.

59 De H., 'Ziekenverpleging', Sumatra Courant (6 January 1897).

60 Frédérique Adler, 'Kreet uit het verre Oosten!', Maandblad voor Ziekenverpleging, 9 (1898-99), 149-50.

61 N. Stokvis-Cohen Stuart, 'De Hollandsche verpleegster in Indië, Maandblad voor Ziekenverpleging, 40 (1930), 412-5. Italics in the original.

62 J. W. Gunning, De medische zending (Baarn: Hollandia drukkerij, 1911), p. 40.

63 Mrs [L. L.] Bervoets-van Ewijck, 'De opleiding en vorming van inlandsche ziekenverpleegsters', Maandberichten van het Nederlandsche Zendelinggenootschap, 99 (1897), 169-82, esp. 171-2, 174.

64 Th. J. A. Hilgers and C. Lekkerkerker, Populaire schetsen over land en volk van Indië (Amsterdam: Tijdschrift voor ziekenverpleging, 1920), p. 51.

65 Reply from Minister Rauws to Sister G. Haandrikman dated 20 September 1924, Utrechts archief, Raad voor de Zending (toegangsnr 1102-1), inventory no. 2322.

66 Stokvis-Cohen Stuart, Inlandsche Ziekenverpleging Semarang, p. 2.

67 C. M. E. Kuyper, Jaarverslag Petronella, 16 (1912), 13-18. 
68 In 1917 all nine student midwives were titled, as were eighteen out of forty-one female student nurses, while four out of six male nurses were titled, and twelve out of twenty-eight male student nurses, Jaarverslag Semarang, 4 (1918), 29-31.

69 Stokvis-Cohen Stuart, Inlandsche Ziekenverpleging Semarang, pp. 12-14. Italics in the original.

70 Stokvis-Cohen Stuart, 'Plan wijkverpleging', 5-6.

71 Gunning, Medische Zending, p. 18.

72 J. H. Abendanon, De opvoeding van inlandsche meisjes in Ned.-Indië ('s-Gravenhage: n.p., 1909), p. 6; offprint from the report of the exhibition 'Opvoeding van het kind'.

73 Jaarverslag Semarang, 6 (1920), 11.

74 Bervoets-van Ewijck, 'De opleiding en vorming', 170, 176.

75 Quotations from, respectively, the Bataviaasch Nieuwsblad (22 November 1900) and a local Yogyakarta newspaper, both included in Jaarverslag Petronella, 5 (1901), pp. 47-8.

76 Meijer, Gedenkboek, p. 34.

77 A. J. Duymaer van Twist and A. Pijsel, 'Verslag van het ziekenhuis te Madja-warna over het jaar 1905', Mededeelingen van Wege het Nederlandsche Zendelingengenootschap, 50 (1906), 137-41, esp. 138.

78 In a letter dated 10 June 1902, Jaarverslag Petronella, 7 (1903), p. 9.

79 'Jaarverslag van den Burgerlijken Geneeskundigen Dienst in Nederlandsch-Indië over 1921', in Mededeelingen van den Burgerlijken Geneeskundigen Dienst in Nederlandsch-Indië (Batavia: Kolff, 1923), pp. 327-461, esp. 328.

80 F. Gouda, Dutch Culture Overseas: Colonial Practice in the Netherlands Indies 1900-1942 (Amsterdam: Amsterdam University Press, 1995), pp. 118-57, devotes a whole chapter to the matter: the native 'other' as the medieval, childlike and animal 'self'. Something similar can be witnessed in British India: M. Sinha, Colonial Masculinity: The 'Manly Englishman' and the 'Effeminate Bengali' in the Late Nineteenth Century (Manchester: Manchester University Press, 1995).

81 Many European physicians doubted whether the dokter djawa - after no less than ten years of medical training - were actually capable of working independently. Hesselink, Healers on the Colonial Market, p. 194.

82 Locher-Scholten, Women and the Colonial State, p. 92.

83 Sciortino, 'Care-takers of cure', pp. 61-2.

84 Some 14,000 girls attended school on Java and Madura in 1912; 8,081 at governmental schools, 5,745 at private schools. In addition, about 6,000 attended a desa (village) school, but this did not grant admission to nursing training. On the other islands, some 32,000 girls received education, but there was hardly any nursing training there. Numbers from J. H. Abendanon, Het onderwijs in Ned.-Indië, meer in het bijzonder dat bestemd voor de meisjes, 
n.p.: n.d. [signed Amsterdam, June 1913]; lecture at the exhibition 'De vrouw [The Woman] 1813-1913', p. 10.

85 Jaarverslag Semarang, 2 (1916), 7.

86 From a letter by Dr Pruys dated 31 January 1908, Jaarverslag Petronella, 12 (1908), p. 7 and Jaarverslag Semarang, 4 (1918), 13, respectively.

87 Jaarverslag Petronella, 8 (1904), 18, mentions married and unmarried native male nurses.

88 Jaarverslag Semarang, 8 (1922), 11. 